\title{
Partisipasi Ibu Rumah Tangga dalam Pengelolaan Sampah melalui Bank Sampah di Desa Ragajaya, Bojonggede - Bogor Jawa Barat
}

\author{
Muhtar Mochamad Solihin¹, Pudji Muljono², Dwi Sadono² \\ ${ }^{1}$ Program Studi Ilmu Penyuluhan Pembangunan - Sekolah Pascasarjana Institut Pertanian Bogor (IPB); \\ e-mail: muhtarms@apps.ipb.ac.id
}

2Departemen Sains Komunikasi dan Pengembangan Masyarakat - Fakultas Ekologi Manusia - IPB

\begin{abstract}
ABSTRAK
Partisipasi ibu rumah tangga dalam pengelolaan sampah melalui bank sampah dapat menyelesaikan masalah sampah yang semakin meningkat. Terlebih lagi jumlah bank sampah di Indonesia mengalami peningkatan yang cukup signifikan. Namun di sisi lain Jambeck et.al (2015) menemukan bahwa Indonesia menjadi negara tertinggi kedua dunia yang paling banyak membuang sampah plastik ke laut setelah China. Hal tersebut menjadi fenomena yang cukup penting dan menarik untuk dikaji terkait partisipasi ibu rumah tangga yang tergabung di bank sampah. Partisipasi ibu rumah tangga tersebut dapat saja tidak berkelanjutan sehingga fenomena Indonesia menjadi penghasil sampah tertinggi kedua muncul ke permukaan. Oleh karena itu, penelitian ini bertujuan untuk menganalisis faktor-faktor yang berhubungan dengan tingkat partisipasi ibu rumah tangga dalam pengelolaan sampah melalui bank sampah. Penelitian ini dilakukan di lima kelompok bank sampah binaan Yayasan Bunga Melati Indoneisa yang berada di Desa Ragajaya, Kecamatan Bojonggede Kabupaten Bogor. Pendekatan penelitian menggunakan pendekatan kuantitatif dengan metode survey. Jumlah sampel sebanyak 73 orang yang ditentukan menggunakan rumus slovin dari jumlah populasi sebanyak 266 orang. Data sampel dianalisis menggunakan analisis deskriptif dan inferensial (rank Spearman). Hasil penelitian menunjukkan bahwa usia responden masuk dalam kategori produktif dengan variasi antara 28 hingga 61 tahun. Tingkat pendidikan formal dalam kategori menengah antara SMP hingga SMA. Tingkat pengetahuan ibu rumah tangga tergolong sedang cenderung tinggi sehingga tidak ada responden yang berpengetahuan rendah. Ibu rumah tangga berpartisipasi dalam pengelolaan sampah melalui bank sampah dengan faktor pendukung seperti tingkat pengetahuan, tingkat ketersediaan infrastruktur, dan tingkat dukungan keluarga. Peningkatan pengetahuan ibu rumah tangga tentang bahaya sampah yang tidak dikelola akan meningkatkan keterlibatan mereka dalam pengelolaan sampah melalui bank sampah.
\end{abstract}

Kata kunci: Bank Sampah, Partisipasi Ibu Rumah Tangga, Pemberdayaan Masyarakat, Pengelolaan Sampah Rumah Tangga, Tingkat Pengetahuan Ibu Rumah Tangga dalam pengelolaan sampah

\begin{abstract}
The participation of housewife in waste management through trash bank can solve the increasing waste problem. The amount of trash bank is increasing in Indonesia, but on the other hand Jambeck et.al (2015) found that Indonesia became the second highest country in the world to dump plastic waste into the sea after China. This has become an important and interesting phenomenon to be studied related to the participation of housewife in the trash bank. The participation of this housewife may not be sustainable so that the phenomenon of Indonesia being the highest producer of waste comes to the surface. Therefore, this study aims to analyze the factors associated with the level of participation of housewives in waste management through the trash bank. This research was carried out in five garbage banks of the Yayasan Bunga Bunga Melati Indonesia located in Ragajaya Village, Bojonggede District, Bogor Regency. The research approach uses a quantitative with survey methods. The sample is 73 people determined using the Slovin formula of a population of 266 people. Sample data were analyzed using descriptive and inferential analysis (the rank of Spearman). The results showed that the age of the respondents included in the productive category with variations between 28 to 61 years. The level of formal education is in the middle category between junior high and high school. The level of knowledge of housewife is classified as moderate so that no respondent has low knowledge. Housewife agree on waste management through a trash bank with supporting factors such as level of knowledge, level of infrastructure support, and level of family support. Increasing knowledge of housewife about the dangers of unmanaged waste will increase their savings in waste management through the trash bank
\end{abstract}

Keywords: Trash Bank, Community Empowerment, Housewife's Participation, Waste Management, The level of Knowledge in Waste Management

Citation: Solihin, M. M., Muljono, P., dan Sadono, D.(2019). Partisipasi Ibu Rumah Tangga dalam Pengelolaan Sampah melalui Bank Sampah di Desa Ragajaya, Bojonggede - Bogor Jawa Barat. Jurnal Ilmu Lingkungan, 17(3),388-398, doi:10.14710/jil.17.3.388-398 


\section{PENDAHULUAN}

Pemberdayaan masyarakat merupakan salah satu strategi mencapai tujuan pembangunan nasional Bangsa Indonesia yang tercantum dalam Pembukaan UUD 1945, yakni “... melindungi segenap bangsa Indonesia dan seluruh tumpah darah Indonesia dan untuk memajukan kesejahteraan umum, mencerdaskan kehidupan bangsa, dan ikut melaksanakan ketertiban dunia yang berdasarkan kemerdekaan, perdamaian abadi dan keadilan sosial....". Maka dari itu kegiatan pemberdayaan perlu diimplementasikan secara utuh dan menyeluruh sehingga menjamin adanya perubahan yang positif dari masyarakat. Salah satu program tersebut dapat diperankan oleh lembaga sosial bersama masyarakat yang tidak hanya mengejar perubahan pada aspek kesejahteraan (ekonomi) semata, tetapi juga pada aspek sosial dan lingkungan.

Pemberdayaan yang berwawasan sosial dan lingkungan diharapkan mampu menyelesaikan berbagai persoalan bangsa yang ada seperti kemiskinan, ketimpangan pendidikan sampai pada masalah sampah yang semakin hari semakin meningkat. Salah satu program yang dapat dikembangkan guna mencapai tujuan menyelesaikan beragam persoalan tersebut adalah kegiatan pemberdayaan masyarakat melalui gerakan pengelolaan sampah melalui bank sampah. Gerakan tersebut tidak hanya dapat mengubah sampah menjadi berkah, tetapi juga mengubah pengetahuan dan perilaku masyarakat untuk hidup bersih dan sehat.

Salah satu pihak yang dapat secara maksimal menjalankan kegiatan bank sampah adalah Ibu rumah tangga karena mereka merupakan pihak yang dekat dengan masalah sampah di rumah. Selain itu, ibu rumah tangga tidak hanya dianggap yang paling mengetahui persoalan sampah di rumah, tapi juga dianggap mampu memberikan kontribusi nyata atas pengelolaan sampah rumah tangga. Oleh karena itu partisipasi ibu rumah tangga dalam kegiatan pengelolaan sampah melalui bank sampah mulai dari sumbernya menjadi menjadi penting dan menarik untuk dikaji lebih dalam.

Menurut Zulkifli (2014) sampah yang tidak dikelola dengan baik akan menimbulkan gangguan terhadap lingkungan, seperti fisik kimia, biologi, sosial ekonomi, budaya dan kesehatan lingkungan juga akan memicu terjadinya konflik sosial antar komponen masyarakat. Dampak lainnya adalah menimbulkan berbagai penyakit seperti diare, kolera, tifus dan lain-lain. Maka partisipasi ibu rumah tangga dalam kegiatan bank sampah dapat menjadi salah satu solusi untuk menangani masalah sampah. Bahkan, apabila seluruh ibu rumah tangga berpartisipasi aktif dalam mengelola sampah, maka tidak menutup kemungkinan bahwa masalah sampah akan terselesaikan dengan optimal.

Hanya saja mendorong ibu rumah tangga untuk berpartisipasi aktif dalam mengelola sampah melalui bank sampah bukanlah hal yang mudah. Alasannya karena ibu rumah tangga memiliki peran ganda yang selain memiliki tugas domestik untuk mengurus rumah tangga tapi juga tak jarang memiliki karir di ranah publik. Maka ketika mereka memutuskan untuk berpartisipasi, seorang ibu harus mampu membagi waktu lagi yang lebih ketat antara rumah, kantor dan kegiatan bank sampah. Meskipun demikian, tidak sedikit kelompok bank sampah mulai berdiri di berbagai wilayah yang pengelolanya hampir mayoritas adalah ibu rumah tangga. Kementerian Lingkungan Hidup (2015) mencatat terdapat peningkatan jumlah bank sampah dari 1.640 pada tahun 2011 menjadi 2.861 unit pada tahun 2015. Peningkatan tersebut sejalan dengan jumlah sampah yang terkelola di bank sampah dari $2.347,8$ ton/ bulan menjadi 5.551 ton/ bulan.

Namun peningkatan jumlah tersebut tidak diiringi dengan pembinaan secara konsisten dan menyeluruh sehingga menyebabkan kegiatan bank sampah ada yang tidak berkelanjutan. Yayasan Bunga Melati Indonesia (YBMI) yang menginisiasi dan membina bank sampah di berbagai wilayah menyebutkan bahwa terdapat bank sampah binaannya yang terlah berdiri berhenti dari kegiatan rutin. Padahal kegiatan pengelolaan sampah melalui bank sampah terbukti mampu mengurangi volume sampah yang dihasilkan masyarakat. Pratama dan Ihsan (2017) menyebut bahwa bank sampah Malang di Jawa Timur dapat mengurangi volume sampah sebanyak $663,720 \mathrm{~kg} /$ tahun.

Hal yang sama diungkapkan Permanasari dan Damanhuri (2012) bahwa pengelolaan sampah melalui bank sampah di Bandung dapat mengurangi sampah sebanyak $0,417 \mathrm{~kg} / \mathrm{orang} / \mathrm{hari}$. Selain itu Shentika (2016) menyebut bahwa pengelolaan sampah melalui bank sampah di Probolinggo mampu mengurangi timbulan sampah di lingkungan mereka. Bahkan Dwiyanto (2011) menyebutkan pengelolaan sampah rumah tangga berbasis masyarakat di Semarang berhasil mengurangi volume sampah yang dibuang mencapai 70 persen.

Isu penting pengelolaan sampah saat ini masih rendahnya keterlibatan masyarakat dalam melaksanakan program yang ada secara berkelanjutan. Levis (1996) menyebutkan bahwa rendahnya partisipasi masyarakat karena adanya ketidak-pedulian dari program yang bersangkutan terhadap masalah serta kondisi sosial ekonomi dan budaya masyarakat setempat. Selain itu lemahnya koordinasi aparat pelayanan dari instansi terkait juga menjadi penyebab lemahnya partisipasi masyarakat terutama dalam melaksanakan inovasi pembangunan yang diberikan. Amal dan Baharuddin (2016) dan Tanjung et al. (2017) menjelaskan bahwa kurangnya partisipasi masyarakat akibat kurangnya kesempatan yang diberikan kepada masyarakat dalam pengelolaan. Hal yang sama ditemukan Adi dan Rahdriawan (2016) bahwa pemerintah belum 
sepenuhnya menunjukkan komitmen dalam memberikan kesempatan kepada masyarakat.

Partisipasi itu sendiri menurut Mardikanto (2010) adalah keikutsertaan seseorang atau sekelompok anggota masyarakat dalam suatu kegiatan. Slamet (2003) mengartikan partisipasi sebagai ikut sertanya masyarakat dalam pembangunan, ikut dalam kegiatan-kegiatan pembangunan, dan ikut serta memanfaatkan dan menikmati hasil-hasil pembangunan. Wardojo (1992) menjelaskan partisipasi sebagai keikutsertaan masyarakat baik dalam bentuk kegiatan maupun pernyataan sebagai hasil dari interaksi sosial antara individu dengan masyarakat lain.

Hasil penelitian terkait partisipasi masyarakat dalam pengelolaan sampah yang sudah dilakukan oleh Adawiyah et al. (2012) melihat partisipasi pada tiga tahapan, yaitu perencanaan, pelaksanaan dan pengawasan. Dalam penelitian ini berupaya melihat partisipasi sebagai keterlibatan responden dalam mengikuti perencanaan, pelaksanaan, evaluasi, dan pemanfaatan hasil pengelolaan sampah rumah tangga melalui bank sampah.

Keberhasilan pengelolaan sampah melalui bank sampah tidak terlepas dari partisipasi ibu rumah tangga yang sudah berjalan lebih dulu secara berkelanjutan dibandingkan dengan lokasi penelitian. Bank sampah di lokasi penelitian ini baru terbentuk pada tahun 2013 sebagai hasil inisiasi dari pihak luar warga sekitar. Oleh karena itu, menjadi penting dan menarik untuk dilakukan penelitian dengan tujuan menganalisis faktor-faktor yang berhubungan dengan tingkat partisipasi ibu rumah tangga dalam pengelolaan sampah melalui bank sampah secara berkelanjutan.

\section{METODE PENELITIAN}

Penelitian ini menggunakan pendekatan analisis kuantitatif yang didukung data kualitatif. Di sini peneliti menguji hubungan antara faktor internal dan faktor eksternal dengan tingkat partisipasi ibu rumah tangga dalam pengelolaan sampah melalui bank sampah. Populasi dalam penelitian ini adalah Ibu rumah tangga pada 5 kelompok bank sampah di Desa Ragajaya Kecamatan Bojonggede Kabupaten Bogor berjumlah 266 orang. Jumlah sampel yang diambil sebanyak 73 orang yang ditentukan menggunakan rumus Slovin dengan tingkat kesalahan (margin error) 10 persen pada derajat kebenaran 90 persen (Prasetyo dan Jannah, 2006).

Teknik pengambilan sampel pada masing-masing kelompok dilakukan dengan menggunakan acak sederhana (simpel random sampling) karena populasi dianggap sama sehingga tidak memperhatikan tingkatan yang ada dalam populasi (Sugiyono, 2011). Jumlah responden sebanyak 73 orang dari jumlah populasi sebanyak 266 orang. Guna mendukung pemaknaan hasil penelitian, peneliti menarik informan diluar responden sebanyak 10 orang dengan karakteristik yang terlibat cukup aktif dan 390 memiliki tanggungjawab lebih dibandingkan yang lainnya, sehingga dapat memberikan keterangan tambahan mengenai data penelitian. Informan tersebut yaitu: Sekretaris Yayasan Bunga Melati Indonesia, Koordinator Bank Sampah Desa Ragajaya, Ketua Bank Sampah teraktif, dan sisanya adalah nasabah Bank Sampah.

\subsection{Sumber Data}

Penelitian ini menggunakan data primer dan data sekunder. Data primer diperoleh melalui wawancara kepada responden menggunakan daftar pernyataan yang telah disiapkan dan observasi langsung ke lokasi penelitian. Data sekunder yang digunakan berupa data dokumen, baik dari instansi pemerintah Desa Ragajaya, lembaga swadaya masyarakat (YBMI) dan kepustakaan lain yang terkait dengan penelitian. Data sekunder yang dicari mengenai keadaan umum wilayah, kependudukan dan jumlah bank sampah binaan YBMI, termasuk struktur sosial masyarakat Desa Ragajaya Kecamatan Bojonggede Bogor.

\subsection{Analisis Data}

Analisis data penelitian mengunakan statistik deskriptif dan inferensial. Statistik deskriptif untuk menggambarkan peubah faktor internal, faktor eksternal, dan tingkat partisipasi pengelolaan sampah menggunakan tabel distribusi frekuensi dan persentase. Uji statistik inferensial digunakan untuk melakukan generalisasi sampel terhadap populasi atau menguji hipotesis penelitian (Bungin, 2005). Oleh karena itu uji statistik inferensial dalam penelitian ini menganalisis hubungan antara faktor internal dan faktor eksternal dengan tingkat partisipasi. Analisis statistik inferensial tersebut menggunakan korelasi rank order/peringkat (Spearman).

\section{HASIL DAN PEMBAHASAN \\ 3.1. Karakteristik Responden}

Pengelola sampah melalui bank sampah di Desa Ragajaya Kecamatan Bojonggede Kabupaten Bogor Jawa Barat seluruhnya adalah ibu rumah tangga dengan karakteristik seperti diuraikan di bawah ini:

\subsubsection{Umur}

Umur dalam penelitian ini dikategorikan menjadi tiga golongan yang terdiri dari muda (28-39 tahun), dewasa (40-50 tahun) dan tua (51-61 tahun). Hasil penelitian ini diketahui bahwa umur rata-rata responden di lima bank sampah lokasi penelitian adalah 44 tahun dengan variasi berkisar dari 28 tahun sampai dengan 61 tahun. Hal tersebut menggambarkan bahwa umur responden masih tergolong pada kelompok penduduk produktif (Kemenkes, 2016). Artinya responden masih mampu untuk melakukan suatu hal yang bermanfaat bagi dirinya, keluarganya dan lingkungannya.

Oleh karena itu usia produktif dapat menjadi salah satu faktor responden mau dan mampu 
berpartisipasi untuk menerima dan menerapkan suatu inovasi dalam upaya meningkatkan kualitas diri dan lingkungan. Hal tersebut sesuai dengan Ankesa, Amanah \& Asngari (2016) yang menjelaskan bahwa responden yang berusia produktif secara fisik masih mampu untuk melakukan kegiatan kelompok peduli lingkungan. Selain itu usia produktif menjadikan seseorang semakin matang sehingga akan semakin mudah dalam menerima inovasi untuk kegiatan terkait lingkungan agar lebih baik dari sebelumnya.

\subsubsection{Pendidikan Formal}

Tingkat pendidikan formal responden dalam penelitian ini merupakan jumlah tahun sekolah formal yang ditempuh Ibu rumah tangga pengelola sampah melalui bank sampah sampai penelitian ini berlangsung. Tingkatan tersebut dibagi ke dalam tiga kategori, yaitu rendah (0-6 tahun) setara dengan $\leq$ SD, sedang (7-12 tahun) setara dengan SMP-SMA dan tinggi (13-18 tahun) yang setara dengan D1-S2. Hasil penelitian menunjukkan bahwa pendidikan formal responden sebagian besar (63 persen) pada kategori sedang yang menamatkan pendidikan antara 7 hingga 12 tahun atau setara antara SMP sampai dengan SMA.

Pendidikan formal tersebut menjadi bagian penting dalam membentuk kemampuan seseorang untuk berpikir dan bertindak dalam suatu kegiatan. Artinya semakin tinggi pendidikan maka akan semakin tinggi pula pola pikir seseorang termasuk cara merespons suatu hal, sebaliknya semakin rendah pendidikan maka akan semakin lebih sulit seseorang menerima informasi baru dan bertindak dalam suatu kegiatan. Johanto (2010) menjelaskan bahwa pendidikan menjadi modal untuk mendorong dan mengubah kesadaran, kehidupan dan keinginan seseorang untuk maju lebih baik lagi dalam lingkungannya.

\subsubsection{Tingkat Pengetahuan}

Tingkat pengetahuan responden sebagian besar (53 persen) masih berada pada kategori sedang cenderung tinggi. Artinya Ibu rumah tangga yang tergabung dengan kelompok bank sampah di Desa Ragajaya semuanya mengetahui bahaya sampah yang tidak dikelola dengan baik. Pengetahuan tersebut diperoleh melalui obrolan sederhana, tontonan televisi dan pendidikan nonformal yang diikuti. Sebagian besar responden (66 persen) mengaku pernah mengikuti kegiatan pendidikan nonformal berupa penyuluhan maupun pelatihan terkait pengelolaan sampah rumah tangga.

Tingkat pengetahuan ini dapat menjadi sumber informasi ibu rumah tangga untuk memutuskan terlibat atau tidak dalam kegiatan pengelolaan sampah. Hasil observasi di lapangan menggambarkan bahwa responden mengetahui bahaya sampah yang tidak dikelola sehingga akhirnya memutuskan untuk terlibat dalam kegiatan bank sampah. Tujuan utama responden mengikuti bank sampah tidak semata karena nilai ekonomi, melainkan untuk menjaga lingkungan agar tetap terjaga dari bahaya sampah yang tidak dikelola. Hal ini seperti yang diungkapkan nasabah bank sampah di wilayah Anggrek sebagai berikut:

“...Untuk mengurangi polusi udara, kan kalo dibakar sampah jadi polusi udara, untuk menjaga kebersihan lingkungan" (Ibu M, 47 tahun, nasabah bank sampah Anggrek)

Hal tersebut menunjukkan bahwa ibu rumah tangga yang terlibat di bank sampah khususnya di bank sampah Anggrek memiliki pengetahuan yang cukup tentang bahaya dari sampah yang tidak dikelola dengan baik dan benar. Oleh karena itu, pengetahuan ini menjadi salah satu faktor yang dapat meningkatkan keterlibatan ibu rumah tangga dalam kegiatan pengelolaan sampah melalui bank sampah.

\subsection{Tingkat Partisipasi Ibu Rumah Tangga dalam Pengelolaan Sampah melalui Bank Sampah di Desa Ragajaya Bogor}

Kegiatan pengelolaan sampah melalui bank sampah di Desa Ragajaya mulai berjalan pada tahun 2013. Kegiatan tersebut merupakan hasil kerjasama dari program pemberdayaan yang dilakukan oleh perguruan tinggi (UIN Jakarta) bersama Yayasan Bunga Melati Indonesia (YBMI) dengan Kementerian Perlindungan Perempuan dan Anak (KPP\&A). Kegiatan bank sampah tersebut diimplementasikan melalui jalan pemberdayaan partisipatif sehingga pengelolaannya dilakukan sepenuhnya oleh ibu rumah tangga sekitar. Keberhasilan bank sampah pertama ini menjadi sumber motivasi lahirnya bank sampah lain di Desa Ragajaya. Dalam kurun waktu 4 tahun dari tahun 2013 hingga 2017, bank sampah yang ada di Desa Ragajaya sudah mencapai 10 unit.

Peningkatan tersebut mengindikasikan adanya kemauan dari warga sekitar untuk terlibat dalam pengelolaan sampah melalui bank sampah. Kegiatan yang dijalankan ibu rumah tangga di bank sampah mulai dari memilah sampah di rumahnya masingmasing sesuai jenisnya, membawa sampahnya ke tempat bank sampah, pengurus bank sampah melakukan penimbangan dan pencatatan sampah yang dibawa nasabah tersebut, kemudian hasil timbangan sampah dicatat ke dalam buku besar dan buku tabungan nasabah. Sampah yang terkumpul saat penimbangan tersebut langsung diangkut oleh pengepul yang sudah bekerjasama dengan bank sampah untuk dibeli dan dijual ke pengepul yang lebih besar.

Selain rutinitas penimbangan sampah, ibu rumah tangga yang tergabung di bank sampah dilibatkan untuk mengikuti kegiatan penyuluhan maupun pelatihan mengelola sampah. Manfaat kegiatan tersebut dapat meningkatkan pengetahuan ibu rumah tangga tentang bahaya sampah yang tidak dikelola dengan baik. Selain itu, ibu rumah tangga 
yang mengikuti pelatihan menjadi lebih terlatih untuk mengolah sampah non organik menjadi produk kerajinan tangan seperti tas jinjing, vas bunga, ataupun barang lainnya yang bernilai ekonomi.

Pengembangan kegiatan bank sampah yang ada dengan cara diikutsertakan dalam kegiatan lomba antara bank sampah yang diselenggarakan perusahaan swasta (garuda food) maupun pemerintah. Salah satu perlombaan lingkungan yang diselenggarakan pemerintah menjadikan Desa Ragajaya dikenal oleh daerah lain karena bank sampah bersama PKK yang mengikuti lomba menjadi juara 2 di tingkat provinsi. Hal ini menjadikan kegiatan bank sampah terus berkembang dan mengalami peningkatan jumlah.

Meskipun demikian, di sisi lain laju pertumbuhan penduduk yang tinggi berbanding lurus dengan tingkat kebutuhannya sehingga berakhir dengan bertambahnya volume sampah dengan jenis yang semakin beragam. Selama 3 tahun (2014-2017), Kementerian Lingkungan Hidup menyebutkan bahwa volume sampah mengalami peningkatan dari yang hanya 64 juta ton menjadi 65,8 juta ton per tahun. Volume sampah tersebut diproyeksikan akan mengalami peningkatan pada tahun 2019 menjadi 67,1 juta ton (INDII, 2017).

Jenis dan volume sampah yang terus meningkat tersebut perlu segera dilakukan pengelolaan secara efektif dan efisien guna menekan dampak negatif terhadap lingkungan. Pengelolaan sampah utamanya adalah pengelolaan lingkungan yang dalam pemanfaatannya untuk menjaga keseimbangan atau melestarikan fungsi lingkungan. Zulkifli (2014) menjelaskan bahwa pengelolaan lingkungan merupakan upaya terpadu dalam memanfaatkan, menata, memelihara, mengendalikan, memulihkan dan mengembangkan lingkungan hidup.

Sementara itu, undang-undang nomor 18 tahun 2008 tentang pengelolaan sampah menjelaskan bahwa pengelolaan sampah merupakan kegiatan yang sistematis, menyeluruh dan berkesinambungan meliputi pengurangan dan penanganan sampah. Hasil penelitian ini menggambarkan bahwa kegiatan pengelolaan sampah binaan Yayasan Bunga Melati Indonesia (YBMI) di Desa Ragajaya Bogor sudah diselenggarakan berdasarkan asas tanggung jawab, asas berkelanjutan, asas manfaat, asas keadilan, asas kesadaran, asas kebersamaan, asas keselamatan, asas keamanan, dan asas nilai ekonomi. Kegiatan tersebut dijalankan dengan cara memberdayakan masyarakat agar mereka tahu, mau dan mampu untuk mengelola sampah sehingga berdampak positif tidak hanya pada kesejahteraan (ekonomi) keluarga, tetapi juga pada aspek sosial dan lingkungan.

Menurut Salim (2010) penyetaraan ketiga aspek tersebut dipandang perlu mengingat paradigma pembangunan konvensional telah berubah menjadi pembangunan berkelanjutan yang menganggap perbaikan sosial dan lingkungan sama pentingnya dengan pertumbuhan ekonomi. Sementara selama ini 392 penerapan pembangunan konvensional hanya meletakkan ekonomi sebagai pusat persoalan pertumbuhan, sedangkan sosial dan lingkungan pada posisi yang kurang penting. Oleh karena itu sekalipun pembangunan konvensional berhasil meningkatkan pertumbuhan ekonomi, tetapi gagal dalam aspek sosial dan lingkungan.

Selain itu, manfaat dari kegiatan bank sampah ini menjadi bagian yang tidak terpisahkan dari pendidikan keluarga karena secara tidak langsung Ibu rumah tangga telah mendidik keluarganya untuk dapat mengelola sampah di rumah. Amatan di lapangan terlihat bahwa anak dari ibu rumah tangga yang tergabung di bank sampah sudah mampu menyimpan sampah sesuai jenisnya di tempat yang sudah disediakan. Hal ini seperti yang diungkapkan ketua bank sampah Griya sebagai berikut:

“....Saya bilang (ke keluarga) di dapur ada paku-paku yang mana ini plastik buat naro (sampah) kertas, ini plastik buat naro (sampah) aqua. Makanya anak saya kalau abis minum (aqua) taro (di tempatnya), udah tahu tuh dia sekarang ditaro di sampah yang tempat aqua" (Ibu K, 48 tahun, ketua bank sampah Lembah Griya)

Bahkan anak lainnya tanpa rasa malu untuk mengumpulkan sampah di sekolahnya dan dibawa pulang untuk diberikan kepada ibunya. Hal ini seperti yang diungkapkan sekretaris bank sampah Lembah Griya sebagai berikut:

"anak saya laki-laki loh, dia gak malu. ..jadi temennya yang di kantin itu, dia selalu minta temennya kumpulin 'buat mamahku' gitu. ...'kok gak malu?' (alasan dia) 'ngapain harus malu, kan mamah ngajarin aku untuk hidup bersih dan ngasilin uang', nanti dia timbang 'mah dapet berapa?' buat nabung". (Ibu N, 48 tahun, sekretaris bank sampah Lembah Griya)

Perubahan perilaku (gaya) hidup bersih dan sehat tersebut menjadi tujuan utama dari gerakan bank sampah yang dikelola oleh Yayasan Bunga Melati Indonesia (YBMI) ini. Yayasan mengungkapkan bahwa kegiatan bank sampah tiada lain bukan semata untuk tujuan mencari keuntungan ekonomi, melainkan untuk menggerakkan kesadaran masyarakat sehingga mereka tahu, mau dan mampu berperilaku hidup bersih dan sehat. Hal ini sesuai dengan ungkapan staff yayasan Bunga Melati Indonesia adalah sebagai berikut:

“...jelas beda kan, antara mengelola sampah untuk tujuan perubahan perilaku hidup bersih dengan mengelola sampah untuk bisnis?. ...Pemerintah kota bahkan sampai tingkat Kementerian hanya untuk uang atau ekonomi bukan menitikberatkan ke 
perubahan perilaku masyarakat. ...Ketika melihat seperti itu, maka jelas YBMI dan pemerintah mengalami bentrokan pemahaman terkait tujuan bank sampah."

Berbagai manfaat yang diperoleh masyarakat yang tergabung di bank sampah tersebut sama halnya yang diungkapkan Suwerda (2012) bahwa pengelolaan sampah melalui bank sampah memiliki empat aspek manfaat utama, yang terdiri dari: aspek kesehatan lingkungan, aspek pendidikan, aspek sosial ekonomi, dan aspek pemerintah. Meskipun terdapat manfaat yang bisa diperoleh ketika bergabung dengan bank sampah, namun hasil analisis deskriptif (Tabel 1) menggambarkan bahwa tingkat partisipasi ibu rumah tangga sebagian besar (52 persen) berada pada kategori sedang. Artinya ibu rumah tangga cukup berpartisipasi dalam pengelolaan sampah melalui bank sampah. Hal tersebut dikarenakan tidak semua ibu rumah tangga hanya tinggal di rumah mengurus keluarga, tetapi juga ada yang memiliki pekerjaan di kantor.

Tabel 1. Tingkat Partisipasi Ibu Rumah Tangga dalam Pengelolaan Sampah Melalui Bank Sampah di Desa Ragajaya

\begin{tabular}{|c|c|c|c|c|c|c|c|c|c|c|c|c|}
\hline \multirow{2}{*}{ Kategori } & \multicolumn{2}{|c|}{ Atsiri } & \multicolumn{2}{|c|}{ Griya } & \multicolumn{2}{|c|}{ Anggrek } & \multicolumn{2}{|l|}{ BPI } & \multicolumn{2}{|c|}{ Jingga } & \multicolumn{2}{|c|}{ Total } \\
\hline & $\mathrm{n}$ & $\%$ & $\mathrm{n}$ & $\%$ & $\mathrm{n}$ & $\%$ & $\mathrm{n}$ & $\%$ & $\mathrm{n}$ & $\%$ & $\mathrm{n}$ & $\%$ \\
\hline \multicolumn{13}{|c|}{ Perencanaan Kegiatan } \\
\hline Rendah & 7 & 58 & 8 & 50 & 6 & 33 & 8 & 57 & 6 & 46 & 35 & 48 \\
\hline Sedang & 1 & 8 & 4 & 25 & 5 & 28 & 3 & 21 & 4 & 31 & 17 & 23 \\
\hline Tinggi & 4 & 33 & 4 & 25 & 7 & 39 & 3 & 21 & 3 & 23 & 21 & 29 \\
\hline \multicolumn{13}{|c|}{ Pelaksanaan Kegiatan } \\
\hline Rendah & 0 & 0 & 1 & 7 & 0 & 0 & 0 & 0 & 0 & 0 & 1 & 1 \\
\hline Sedang & 2 & 17 & 6 & 40 & 7 & 39 & 4 & 29 & 2 & 15 & 21 & 29 \\
\hline Tinggi & 10 & 83 & 8 & 53 & 11 & 61 & 10 & 71 & 11 & 85 & 50 & 69 \\
\hline \multicolumn{13}{|c|}{ Evaluasi Kegiatan } \\
\hline Rendah & 5 & 42 & 10 & 63 & 4 & 22 & 13 & 93 & 0 & 0 & 32 & 44 \\
\hline Sedang & 5 & 42 & 3 & 19 & 7 & 39 & 1 & 7 & 2 & 15 & 18 & 25 \\
\hline Tinggi & 2 & 17 & 3 & 19 & 7 & 39 & 0 & 0 & 11 & 85 & 23 & 32 \\
\hline \multicolumn{13}{|c|}{ Pemanfaatan Hasil Pengelolaan Sampah } \\
\hline Rendah & 0 & 0 & 0 & 0 & 0 & 0 & 0 & 0 & 0 & 0 & 0 & 0 \\
\hline Sedang & 6 & 50 & 6 & 38 & 2 & 11 & 3 & 21 & 1 & 8 & 18 & 25 \\
\hline Tinggi & 6 & 50 & 10 & 63 & 16 & 89 & 11 & 79 & 12 & 92 & 55 & 75 \\
\hline \multicolumn{13}{|c|}{ Tingkat Partisipasi dalam Pengelolaan Sampah melalui bank sampah } \\
\hline Rendah & 0 & 0 & 3 & 19 & 0 & 0 & 1 & 7 & 0 & 0 & 4 & 5 \\
\hline Sedang & 8 & 67 & 8 & 50 & 8 & 44 & 8 & 57 & 6 & 46 & 38 & 52 \\
\hline Tinggi & 4 & 33 & 5 & 31 & 10 & 56 & 5 & 36 & 7 & 54 & 31 & 42 \\
\hline Total & 12 & 100 & 16 & 100 & 18 & 100 & 14 & 100 & 13 & 100 & 73 & 100 \\
\hline
\end{tabular}

Tabel 1 juga menunjukkan partisipasi pada tahap perencanaan dalam beberapa kali kegiatan yang sama seperti pelaksanaan kampung wirausaha yang digagas Yayasan bekerjasama dengan GarudaFood tergolong rendah cenderung sedang. Hal tersebut tidak jauh berbeda dari masing-masing bank sampah yang ada bahwa keterlibatan responden tergolong rendah dalam perencanaan dan evaluasi kegiatan yang diadakan bank sampah. Hal ini akibat dari anggota maupun pengurus yang kurang aktif dan tidak terlalu peduli dengan keberlanjutan pengelolaan bank sampah. Mereka lebih memilih untuk terima beres ketika diberikan kesempatan oleh pengurus aktif untuk mengikuti perencanaan atau pun kegiatan lain.

Berdasarkan hasil obervasi di bank sampah Anggrek ditemukan bahwa pengurus aktif sudah berusaha memberikan kesempatan kepada pengurus yang kurang aktif maupun anggota untuk memajukan bank sampah dengan cara memberikan tawaran untuk memegang tanggung jawab dalam salah satu kegiatan, namun tidak ada respon yang positif dari keduanya. Baik anggota maupun pengurus yang kurang aktif tersebut lebih memilih untuk mempercayakan sepenuhnya kepada pengurus aktif ketika diberikan kesempatan dalam beberapa hal. Tidak adanya respon positif tersebut menjadi salah satu penyebab kurangnya keterlibatan responden pada tahap perencanaan dan evaluasi dalam kegiatan yang ada di bank sampah.

Tingkat partisipasi responden pada tahap pelaksanaan sebagian besar (69 persen) tergolong tinggi, sementara hanya sebagian kecil saja (1 persen) reponden yang tidak berpartisipasi dalam pelaksanaan kegiatan. Tabel 1 menunjukkan bahwa sebagian besar (85 persen) tingkat partisipasi Ibu rumah tangga dalam pelaksanaan kegiatan di bank sampah Satria Jingga lebih tinggi dibandingkan bank sampah lainnya. Hal ini karena responden di bank sampah Satria Jingga memiliki kekompakan dan keaktifan dalam penimbangan bank sampah yang dilakukan rutin setiap 2 minggu sekali. Kekompakan dan keaktifan tersebut dapat terjadi karena ketua bank sampah lebih aktif menggerakan ibu rumah tangga untuk aktif terlibat di bank sampah dan nasabah juga merasa cukup bahagia dengan kegiatan yang dilakukan di bank sampah.

Hal tersebut berbeda dengan kondisi yang terjadi di bank sampah Griya yang belum terlihat adanya kekompakan baik antar pengurus maupun pengurus dengan anggota. Berdasarkan hasil observasi di lapangan hanya pengurus aktif saja yang melakukan kegiatan terkait bank sampah, sementara pengurus tidak aktif maupun nasabah tidak mau untuk terlibat lebih jauh dalam kegiatan yang ada di bank sampah selain penimbangan sampah. Hal ini 
seperti yang diungkapkan Ibu KMN selaku ketua bank sampah Griya sebagai berikut:

"Kemarin ada pelatihan cara mengisi pengisian keuangan karna gak ada yang jawab, maka saya lagi saya lagi, yang lain (alasannya) gak ada waktu, gak ada yang bisa,(jawabnya) 'gak bisa gak bisa'.".

Hal yang sama diungkapkan sekretaris bahwa tidak ada pengurus lain maupun anggota yang mau terlibat dalam membuat kerajinan tangan dari sampah non organik. Tidak adanya keterlibatan dalam membuat kerajinan tangan dari sampah plastik karena menganggap kegiatan tersebut hanya membuang waktu dan tidak ada hasil ekonomi yang didapatkan. Terlebih lagi pasar untuk hasil kerajinan tangan dari sampah plastik belum tersedia secara maksimal. Selain itu, tingkat pengetahuan yang kurang terkait pentingnya mengelola sampah dari plastik menjadikan tidak adanya keterlibatan aktif dari pengurus dan anggota lain dalam membuat kerajinan tangan dari sampah plastik. Pengurus dan anggota lain tidak ikut terlibat dalam membuat kerajinan tangan tersebut seperti diungkapkan Ibu N selaku sekretaris bank sampah Lembah Griya:

"Saya dengan bu KMN itu memang satu ide. Jadi sering berantem (koreksi). Katanya 'begini (nempelinnya), 'enggak, begitu loh', 'begini bu'. Sampe jam 2 malem masih 'kayaknya kurang begini deh' gitu. Untuk koreksi, jadi kita dalam rangka apapun begitu. 'Koreksi dong gimana dong?, koreksi kesalahanku mana'. Gak masalah, yang penting di akhir 'aman ya bu ya?', kita saling menyatukan"

Pada tahap evaluasi 44 persen responden tidak terlibat secara aktif dalam kegiatan evaluasi. Hal tersebut sama halnya dengan partisipasi pada tahap perencanaan dalam suatu kegiatan yang diadakan seperti kegiatan kampung wirausaha. Pada tahap evaluasi ini hanya responden di bank sampah Satria Jingga saja yang memiliki tingkat keterlibatan yang lebih tinggi. Alasannya karena kegiatan penimbangan di bank sampah Satria Jingga dilakukan lebih teratur (berkala) sehingga evaluasi sederhana dapat dilakukan ketika penimbangan berlangsung. Selain itu, evaluasi sederhana juga dilakukan melalui obrolan di group WhatsApp. Meskipun demikian, permasalahan rata-rata di semua bank sampah adalah belum memiliki jadwal khusus untuk melakukan evaluasi termasuk belum pernah mengganti kepengurusan sama sekali sejak bank sampah terbentuk.

Partisipasi responden pada tahap pemanfaatan hasil pengelolaan sampah sebagian besar (75 persen) tergolong tinggi. Artinya kegiatan bank sampah diakui responden memiliki manfaat baik pada aspek ekonomi, lingkungan maupun. Berdasarkan observasi di lapangan responden menyatakan setuju bahwa kegiatan yang dijalankan di bank sampah dapat mendatangkan banyak manfaat. Hanya saja, manfaat pada aspek ekonomi dan lingkungan belum dirasakan secara nyata oleh responden di bank sampah Atsiri. Alasannya karena ibu rumah tangga yang tergabung dengan bank sampah bukan untuk mencari keuntungan bersifat materi, melainkan untuk mengisi kegiatan di waktu luang. Oleh karena itu, manfaat ekonomi yang diperoleh di bank sampah tidak digunakan untuk kepentingan sendiri melainkan untuk kegiatan sosial sekitar.

Partisipasi ibu rumah tangga yang terlihat tinggi hanya pada tahap pelaksanaan dan pemanfaatan hasil saja, sementara di tahap perencanaan dan evaluasi masih tergolong rendah sejalan dengan penelitian Gunawan, Barkey \& Hajar (2014) yang menjelaskan bahwa partisipasi masyarakat dalam pengelolaan hutan masih sebatas pada tahap pelaksanaan yang juga menyertakan pemanfaatan hasil. Hal yang sama diungkapkan Sutrisno (2016) bahwa akibat adanya kendala sosialisasi dan dominasi para tokoh kampung menjadikan perencanaan kampung wisata kurang melibatkan warga kampung secara merata.

\subsection{Faktor-Faktor yang Berhubungan dengan Tingkat Partisipasi Ibu Rumah Tangga}

Hasil uji analisis menggunakan korelasi Rank Spearman dengan bantuan SPSS 21 (Tabel 2) menunjukkan bahwa terdapat hubungan nyata antara tingkat pengetahuan, tingkat ketersediaan sarana prasarana, dan tingkat dukungan keluarga dengan tingkat partisipasi ibu rumah tangga dalam pengelolaan sampah. Namun tidak terdapat hubungan nyata antara umur dan tingkat pendidikan formal dengan tingkat partisipasi Ibu rumah tangga dalam pengelolaan sampah melalui bank sampah.

Tabel 2. Nilai koefisien korelasi antara variabel independent dengan tingkat partisipasi dalam pengelolaan sampah melalui bank sampah di Desa Ragajaya

\begin{tabular}{|c|c|c|}
\hline \multirow[t]{2}{*}{ Variabel independent } & \multicolumn{2}{|c|}{$\begin{array}{c}\text { Tingkat Partisipasi dalam } \\
\text { Pengelolaan Sampah melalui } \\
\text { Bank Sampah }\end{array}$} \\
\hline & $r_{s}$ & Sig. (2- tailed) \\
\hline Umur & .029 & .806 \\
\hline Tingkat Pendidikan Formal & .066 & .580 \\
\hline Tingkat Pengetahuan & $.346^{* *}$ & .003 \\
\hline Tingkat Ketersediaan & $.262^{*}$ & .025 \\
\hline Sarana Prasarana & & \\
\hline Tingkat Dukungan Keluarga & $.558^{* *}$ & .000 \\
\hline
\end{tabular}

Artinya keterlibatan Ibu rumah tangga dalam mengelola sampah melalui bank sampah di Desa Ragajaya Bogor tidak tergantung pada umur dan tingkat pendidikan formal melainkan tergantung pada tingkat pengetahuan responden, tingkat ketersediaan sarana prasarana, dan tingkat dukungan keluarga. Semakin tinggi faktor-faktor 
tersebut, maka akan semakin tinggi keterlibatan mereka dalam kegiatan pengelolaan sampah melalui bank sampah.

\subsubsection{Tingkat Pengetahuan}

Terdapat hubungan positif dan signifikan antara tingkat pengetahuan dengan tingkat partisipasi ibu rumah tangga dalam pengelolaan sampah. Pengetahuan sendiri merupakan informasi yang diketahui individu tentang suatu hal sebagai hasil dari pengalaman masa lalu yang memiliki hubungan dengan pendidikan karena melalui pendidikan yang tinggi maka pengetahuan seseorang akan semakin luas. Pendidikan ini tidak terbatas pada pendidikan formal saja tetapi juga pada pendidikan non formal. Meskipun demikian, penelitian ini tidak mencari hubungan antara pendidikan dengan tingkat pengetahuan.

Hasil penelitian ini menjelaskan bahwa tingkat pengetahuan responden berhubungan dengan tingkat partisipasi Ibu rumah tangga dalam pengelolaan sampah. Hal tersebut menegaskan bahwa responden dapat berpartisipasi aktif dalam mengelola sampah melalui bank sampah apabila memiliki pengetahuan cukup terkait bahaya sampah yang tidak dikelola. Hal ini sesuai dengan hasil observasi di lapangan yang menunjukkan bahwa tingkat pengetahuan Ibu rumah tangga yang terlibat dalam kegiatan pengelolaan sampah melalui bank sampah tidak ada yang rendah. Penelitian ini didukung Ankesa, Amanah \& Asngari (2016) yang menjelaskan bahwa tingkat pengetahuan berhubungan nyata dengan tingkat partisipasi ibu rumah tangga dalam kelompok peduli lingkungan. Hal yang sama diungkapkan Abadi (2013) yang menjelaskan bahwa partisipasi masyarakat rendah akibat dari lemahnya tingkat pengetahuan yang dimiliki responden.

\subsubsection{Tingkat Ketersediaan Sarana Prasarana}

Faktor lainnya yang berhubungan dengan tingkat partisipasi adalah tingkat ketersediaan sarana prasarana dan tingkat dukungan keluarga. Artinya terdapat hubungan yang signifikan pada taraf nyata 95 persen antara tingkat ketersediaan sarana prasarana dengan tingkat partisipasi Ibu rumah tangga dalam pengelolaan sampah melalui bank sampah. Hal tersebut menjelaskan bahwa sarana prasarana memberikan kontribusi bagi keterlibatan Ibu rumah tangga dalam pengelolaan sampah.

Hasil tersebut sejalan dengan penelitian Wibisono dan Dewi (2014) yang menunjukkan bahwa kurangnya sarana prasarana seperti tempat sampah di pinggir jalan menjadikan masyarakat tidak berpartisipasi aktif membuang sampah pada tempatnya. Selain itu Hermawan, Amanah \& Fatchiya (2017) dan Posmaningsih (2016) juga menjelasakan bahwa fasilitas memiliki hubungan dengan partisipasi masyarakat. Artinya semakin tersedianya sarana prasarana yang ada, maka akan semakin tinggi partisipasi ibu rumah tangga untuk mengelola sampah di bank sampah. Sebaliknya semakin tidak tersedianya sarana prasarana akan menjadikan partisipasi Ibu rumah tangga semakin rendah.

\subsubsection{Tingkat Dukungan Keluarga}

Faktor lainnya di luar diri Ibu rumah yang berhubungan dengan tingkat partisipasinya adalah tingkat dukungan keluarga. Dukungan keluarga diartikan sebagai bantuan yang diberikan keluarga kepada Ibu rumah tangga dengan mengijinkannya untuk mengikuti kegiatan pengelolaan sampah di bank sampah. Tingkat dukungan keluarga responden sebagian besar (77 persen) tergolong tinggi karena menganggap bahwa bank sampah memberikan manfaat positif untuk pengembangan diri. Bahkan warga di perumahan Griya yang tadinya tidak setuju dengan adanya bank sampah perlahan kemudian mulai menerima keberadaan bank sampah setelah diberikan pemahaman oleh pengurus bank sampah. Hal ini seperti diungkapkan Ibu N selaku sekretaris bank sampah Lembah Griya:

“...jadi istrinya itu, 'aku mau ikut jadi anggota bank sampah'. Suaminya tidak mengijinkan karna malu. Sampai saya sebagai pengurus bank sampah dipanggil. 'Ibu, maksudnya apa?' katanya (ngumpulin sampah) 'kaya orang belangsak'."

Setelah diberikan pemahaman secara langsung tujuan utama bank sampah, maka sudah tidak ada lagi warga yang protes. Saat ini warga sudah mengetahui dan memahami keberadaan bank sampah sehingga saling menghargai terkait pilihan masing-masing. Warga memiliki kebebasan dan kesempatan yang sama untuk mengelola sampahnya secara mandiri melalui bank sampah atau diberikan langsung kepada pemulung. Permasalahan yang sama antar bank sampah yang ada adalah terkait komunikasi dan informasi. Kurangnya informasi dan komuniksi secara intens dari pengurus ke nasabah bahkan ke warga lain menjadikan tujuan dari kegiatan bank sampah kurang diketahui. Bahkan ketua RT Lembah Griya sendiri baru mengetahui lebih jauh tentang bank sampah saat penelitian ini berlangsung yang kemudian menjadi antusias untuk mendukung keberlanjutan bank sampah. Hal ini seperti diungkapkan ketua RT Lembah Griya tersebut sebagai berikut:

“...Kalau diliat keaktifan, Ibu-ibunya terutama cukup bagus sebetulnya. Kalo bapak-bapak, warga ya mungkin terlalu cuek masalah sampah ini. ... kalo itu belum pernah lah saya menyampaikan ke bapakbapak mengenai bank sampah ini. ...tapi emang bagus sih positif termasuk dari RT satu sampe sepuluh. Eu apa, tanggapannya itu. Jadi responnya cukup bagus gitu. Apalagi kalo tahu gini, saya juga pengen ini juga, pengen majuin gitu. Karna selama ini 
saya enggak enggak katakanlah gak perlu gitu. Tapi kalo begitu ini saya pengen ikutan juga. Saya pengen ada inisiatif mengumpulkan ya itu"

Pernyataan ketua RT tersebut mengindikasikan bahwa dukungan keluarga berhubungan dengan tingkat partisipasi karena Ibu rumah tangga diberikan kebebasan untuk berkegiatan di luar rumah selama kegiatannya positif. Dukungan tersebut dapat terjadi ketika keluarga mengetahui informasi secara jelas terkait manfaat dari kegiatan yang sedang dijalankan. Berdasarkan hasil uji korelasi Rank Spearman yang tertuang pada Tabel 2 menunjukkan bahwa koefisien korelasi tingkat dukungan keluarga sebesar .558** dengan nilai signifikansi $.000<0.05$. Artinya terdapat hubungan kuat positif dan signifikan antara tingkat dukungan keluarga dengan tingkat partisipasi Ibu rumah tangga dalam pengelolaan sampah melalui bank sampah.

Hasil tersebut sejalan dengan Ankesa, Amanah \& Asngari (2016) yang menjelaskan bahwa tingkat dukungan keluarga berhubungan dengan tingkat partisipasi Ibu rumah tangga dalam pengelolaan sampah. Penelitian lain yang dilakukan Suyami (2017) pun menunjukkan hal yang sama bahwa dukungan suami bedampak pada partisipasi pemeriksaan infeksi visual asam asetat (IVA) Ibu wanita usia subur. Penelitian lainnya diungkapkan Nadirawati (2011) yang menunjukkan bahwa dukungan kepala keluarga berhubungan dengan partisipasi keluarga dalam program eliminasi (minum obat) filariasis di Desa Majasetra wilayah kerja Puskesmas Majalaya Kabupaten Bandung.

\subsubsection{Umur}

Umur meskipun dapat menjadi faktor penentu dalam belajar dan bekerja termasuk merespons sesuatu hal baru sehingga memungkinkan seseorang terlibat dalam kegiatan (Muchtar, Purnaningsih \& Susanto, 2014; Suroso, Hakim \& Noor, 2014), namun hasil penelitian ini tidak menunjukkan adanya hubungan yang nyata antara umur dengan keterlibatan Ibu rumah tangga dalam mengelola sampah melalui bank sampah. Hal tersebut akibat persebaran data umur responden yang seragam (homogen).

Berdasarkan observasi di lapangan ditemukan bahwa responden yang berusia dewasa maupun yang berusia tua ada yang cukup berpartisipasi dan ada juga yang berpartisipasi aktif dalam kegiatan. Di sisi lain kedua kelompok usia tersebut juga ada yang memiliki tingkat tingkat partisipasi yang rendah. Hal tersebut menjadi penguat bahwa umur bukan menjadi penentu ibu rumah tangga untuk terlibat dalam pengelolaan sampah melalui bank sampah.

Hasil penelitian ini sejalan dengan Sadono (2012); dan Budiman (2013) yang menjelaskan bahwa faktor umur tidak berhubungan dengan tingkat partisipasi. Tanjung, Sadono \& Wibowo (2017) juga menemukan bahwa umur tidak berhubungan dengan tingkat partisipasi masyarakat dalam pengelolaan hutan nagari. Hal tersebut menjelaskan bahwa perbedaan umur baik muda, dewasa maupun tua tidak dapat meningkatkan secara langsung keterlibatan Ibu rumah tangga dalam kegiatan pengelolaan sampah di bank sampah. Hal ini bertolak belakang dengan penelitian Ankesa, Amanah \& Asngari (2016) yang menjelaskan bahwa umur berhubungan dengan tingkat partisipasi perempuan dalam kelompok peduli lingkungan.

\subsubsection{Tingkat Pendidikan Formal}

Selain umur, tingkat pendidikan formal juga menunjukkan hal yang sama bahwa pendidikan formal tidak menjadi sumber penentu secara nyata Ibu rumah tangga terlibat dalam kegiatan pengelolaan sampah melalui bank sampah. Hal ini sejalan dengan Manoso, Palendeng \& Tucunan (2013) dan Budiman (2013) yang menunjukkan bahwa tingkat pendidikan tidak berhubungan dengan tingkat partisipasi. Artinya tinggi rendahnya tingkat pendidikan formal tidak dapat menentukan keaktifan Ibu rumah tangga untuk terlibat dalam pengelolaan sampah.

Berdasarkan hasil observasi di lapangan menunjukkan bahwa hampir sebagian besar (44 persen) tingkat pendidikan formal di bank sampah Anggrek rendah, namun memiliki tingkat partisipasi (56 persen) yang tinggi. $\mathrm{Di}$ sisi lain tingkat pendidikan formal bank sampah Satria Jingga yang sebagian besar (77 persen) sedang pun juga memiliki tingkat partisipasi yang tinggi (54 persen).

Selain itu, bank sampah Atsiri yang rata-rata (50 persen) berpendidikan tinggi memiliki tingkat partisipasi yang sebagian besar (67 persen) sedang. Kedua bank sampah lainnya yaitu bank sampah Griya dan BPI memiliki tingkat pendidikan formal dan tingkat partisipasi yang sama-sama sedanga. Hal tersebut diduga menjadi penyebab tingkat pendidikan formal tidak memiliki hubungan nyata dengan keterlibatan Ibu rumah tangga dalam pengelolaan sampah. Hasil ini bertolak belakang dengan Sawerah (2015), Ankesa, Amanah \& Asngari (2016) dan Hermawan, Amanah \& Fatchiya (2017) yang menunjukkan bahwa tingkat pendidikan formal berhubungan dengan tingkat partisipasi masyarakat.

\section{KESIMPULAN}

Kegiatan pengelolaan sampah oleh ibu rumah tangga yang tergabung dalam kelompok Bank Sampah di Desa Ragajaya diawali melalui kegiatan penyuluhan oleh yayasan Bunga Melati Indonesia (YBMI). Tujuan utama dari kegiatan tersebut untuk mengubah perilaku (gaya) hidup bersih dan sehat guna sekaligus menata lingkungan menjadi asri dan nyaman. Kegiatan bank sampah diimplementasikan melalui jalan pemberdayaan partisipatif ditandai oleh adanya keterlibatan ibu rumah tangga dalam pengelolaan sampah secara menyeluruh dari mulai perencanaan sampai menikmati hasil. Keterlibatan 
ibu rumah tangga tersebut mendapatkan dukungan dari keluarga bahkan pemerintah setempat.

Manfaat positif dari kegiatan bank sampah yang dirasakan ibu rumah tangga menjadi sumber motivasi lahirnya bank sampah lain yang tersebar di Desa Ragajaya. Keterlibatan ibu rumah tangga tersebut dijalankan mulai dari memilah sampah di rumahnya masing-masing, membawa sampahnya ke bank sampah untuk ditabungkan, menimbang dan mencatatkan ke buku tabungan oleh pengurus dan kemudian dijual langsung kepada pengepul yang sebelumnya sudah janjian. Manfaat jangka panjang adalah terjadinya perubahan perilaku masyarakat sehingga memandang sampah menjadi berkah yang pada akhirnya mau dan mampu untuk mengubah kebiasaan yang semula "membuang sampah" dalam praktiknya hanya memindahkan sampah, menjadi "mengelola sampah" dalam artian memilah untuk dimanfaatkan kembali.

Tingkat partisipasi ibu rumah tangga dalam pengelolaan sampah melalui bank sampah tergolong cukup aktif. Hal tersebut perlu dikelola dan dikembangkan agar terus berkelanjutan sehingga lambat laun dapat menyelesaikan permasalahan sampah yang ada. Faktor-faktor pendorong partisipasi ibu rumah tangga dalam pengelolaan sampah di bank sampah yaitu, tingkat pengetahuan, tingkat ketersediaan sarana prasarama dan tingkat dukungan keluarga. Semakin tinggi faktor-faktor tersebut, maka akan semakin tinggi pula ibu rumah tangga terlibat di bank sampah. Sebaliknya, semakin rendah faktor-faktor tersebut dapat menyebabkan rendahnya keterlibatan ibu rumah tangga dalam pengelolaan sampah melalui bank sampah.

\section{DAFTAR PUSTAKA}

Abadi, R.S. 2013. Keberlanjutan pengelolaan sampah domestik di Kampung Menoreh, Kelurahan Sampangan Semarang. Jurnal Pembangunan Wilayah \& Kota. 9 (1): 87-96.

Adawiyah SR, Firmanul AY, Effendy M, Siddiq M. 2012 . Partisipasi masyarakat dalam pengelolaan sampah perkotaan di Kabupaten Kotabaru (studi kasus di Kecamatan Pulau Laut Utara). Journal Enviro Scienteae. 7 (2011): 31-38. ISSN 1978-8096.

Adi I, Rahdriawan M. 2016. Kajian partisipasi masyarakat dalam pengelolaan sanitasi berbasis masyarakat (PSBM) di Kelurahan Mangunharjo Semarang. Jurnal Pengembangan Kota. 4(2): 151159.

Amal, Baharuddin II. 2016. Persepsi dan partisipasi masyarakat dalam pengelolaan hutan mangrove berbasis masyarakat di Kecamatan Suppa Kabupaten Pinrang. Jurnal Scientific Pinisis. 2(1): 1-7.

Ankesa, H., Amanah, S,. Asngari, P.S. 2016. Partisipasi kelompok perempuan peduli lingkungan dalam penanganan sampah di Sub DAS Cikapundung, Jawa Barat. Jurnal Penyuluhan. 12 (2):105-113.

Budiman, R.A. 2013. Partisipasi dan Persepsi Masyarakat dalam Upaya Menjaga Mengelola Lingkungan Hidup dan Mempertahankan Predikat Kota Bersih. Jurnal Ilmu Lingkungan. Tanjung Pinang Kepulauan Riau
Bungin, B. 2005. Metode Penelitian Kuantitatif: Komunikasi, Ekonomi, dan Kebijakan Publik serta Ilmu-ilmu Sosial Lainnya. Jakarta (ID): Kencana Prenanda Media Group.

Dwiyanto, B.M. 2011. Model peningkatan partisipasi masyarakat dan penguatan sinergi dalam pengelolaan sampah perkotaan. Jurnal Ekonomi Pembangunan. 12 (2): 239-256.

Gunawan, K.S., Barkey, R.A., Hajar, M.A.I. 2014. Implementasi Program Pengelolaan Sumberdaya Hutan Bersama Masyarakat dalam Perspektif Pemberdayaan Desa Hutan. Jurnal Digitalisasi Perpustakaan Pusat UNHAS

Hermawan, A., Amanah, S., Fatchiya, A. 2017. Partisipasi pembudidaya ikan dalam kelompok usaha akuakultur di Kabupaten Tasikmalaya, Jawa Barat. Jurnal Penyuluhan. 13 (1):1-13.

[INDII] Indonesia Infrastructure Initiative. 2017. Mengurangi Sampai dengan Olah di Tempat. [internet]. [diakses 2017 November 02]. Tersedia pada: http: // www.indii.co.id/ images/ dx_article file/ 10449/ mengurangi-sampah-dengan-olah-ditempat.pdf.

Jambeck JR, Geyer R, Wilcox C, Siegler TR, Perryman M, Andrady A, Narayan R, Law KL. 2015. Plastic waste inputs from land into the ocean. Journal of Science 347: 768-771 doi: 10.1126/science.1260352.

Johanto, A. 2010. Pengaruh Kondisi Sosial dan Pengetahuan Lingkungan Ibu-ibu Rumah Tangga terhadap Pengelolaan Sampah Rumah Tangga di Kecamatan Nganjuk Kabupaten Nganjuk. Artikel Mahasiswa Jurusan Geografi. Fakultas Ilmu Sosia. Malang (ID): UNM

[KLH]. 2015. Inovasi Pengembangan Bank Sampah Sistem On-Line. [internet]. [diakses 2017 November 04]. Tersedia pada: http:// www.menlhk.go.id/ berita-13inovasi-pengembangan-bank sampah-sistem-online.html

Levis LR. 1996. Komunikasi Penyuluhan Pedesaan. Bandung: Citra Aditya Bakti.

Manoso, F., Palendeng, H., Tucunan, A. 2013. Hubungan Antara Tingkat Pendidikan dan Tingkat Pendapatan dengan Tindakan Pengelolaan Sampah Rumah Tangga di Lingkungan II Keluraghan Sumompo Kevamatan Tuminting Kota Manado. Artikel Kesehatan Masyarakat. Universitas Sam Ratulangi: 16

Mardikanto T. 2010. Komunikasi Pembangunan. Surakarta (ID): UNS Press.

Muchtar, K., Purnaningsih, N., Susanto D. 2014. Komunikasi partisipatif pada sekolah lapangan pengelolaan tanaman terpadu (SL-PTT). Jurnal Komunikasi Pembangunan. 12 (2) : 1-14.

Nadirawati. 2011. Hubungan dukungan kepala keluarga dengan partisipsai keluarga dalam program eliminasi (minum obat) filariasis di Majasetra Kabupaten Bandung. Jurnal Keperawatan Soedirman (The Soedirman Journal of Nursing). 6(1): 47-55

Permanasari, D., Damanhuri, E. 2012. Studi Efektivitas Bank Sampah Sebagai Salah Satu Pendekatan dalam Pengelolaan Sampah Yang Berbasis Masyarakat [internet]. [diakses 2017 November 02] tersedia pada: https:// fa.itb.ac.id/ wp-content/ uploads/ sites / 8/ 2012/ 07/ 15308006-DevitaPermanasari.pdf 
Posmaningsih, D.A.A. 2016. Faktor-faktor yang mempengaruhi partisipasi masyarakat dalam pengelolaan sampah padat di Denpasar Timur. Jurnal Skala Husada. 13 (1): 59-71.

Prasetyo, B., Jannah, L.M. 2006. Metode Penelitian Kuantitatif: Teori dan Aplikasinya. Jakarta (ID): PT. RajaGrafindo Persada

Pratama, RA., Ihsan, IM. 2017. Peluang penguatan bank sampah untuk mengurangi timbulan sampah perkotaan studi kasus: bank sampah Malang. Jurnal Teknologi Linkungan.18 (1): 112-119.

Sadono, D. 2012. Model pemberdayaan petani dalam pengelolaan usaha tani padi di Kabupaten Karawang dan Cianjur, Provinsi Jawa Barat [disertasi]. Bogor (ID): Institut Pertanian Bogor.

Salim, E. 2010. Paradigma Pembangunan Berkelanjutan. Di dalam: Azis IJ, Napitulu LM, Patunru AA, Resosudarmo BP, editor. Pembangunan Berkelanjutan Peran dan Kontribusi Emil Salim. Jakarta (ID): Kepustakaan Pupoler Gramedia (KPG)

Sawerah S .2015. Partisipasi masyarakat dalam pencegahan kebakaran lahan gambut di Kab Mempawah Kalbar [tesis]. Bogor (ID): Institut Pertanian Bogor.

Shentika, P.A. 2016. Pengelolaan bank sampah di Probolinggo. JESP. 8 (1): 92-100. ISSN: 2086-1575.

Slamet M. 2003. Meningkatkan Partisipasi Masyarakat dalam Pembangunan Perdesaan. Di dalam: Yustina I, Sudrajat A, Penyunting. Membentuk Pola Perilaku Manusia Pembangunan: Didedikasikan kepada Prof. Dr. H.R Margono Slamet. Bogor (ID): IPB Press.

Sugiyono. 2011. Metode Penelitian Kuantitatif Kualitatif dan R\&D. Bandung (ID): Alfabeta.
Suroso, H., Hakim, A., Noor, I. 2014. Faktor-faktor yang mempengaruhi partisipasi masyarakat dalam perencanaan pembangunan di Desa Banjaran Kecamatan Driyorejo Kabupaten Gresik. Jurnal Wacana. 17(1):7-15. ISSN: 1411-0199.

Sutrisno. 2016. Predisposisi Partisipasi Masyarakat dalam Perencanaan Kampung Wisata (Studi Kasus Kampung Wisata Santan. Jurnal Agraris. 2(1): 36-49

Suwerda, B. 2012. Bank Sampah (Kajian Teori dan Penerapan) disertai Penerapan Bank Sampah "Gemah Ripah" di Dusun Badegan Bantul. Yogyakarta (ID): Pustaka Rihama

Suyami. 2017. Dampak dukungan suami terhadap partisipasi pemeriksaan inspeksi visual asam asetat (IVA) pada ibu usia subur di Puskesmas Truvuk II Klaten. Jurnal Motorik. 12(24): 51-64

Tanjung, N.S., Sadono, D., Wibowo, C.T. 2017. Tingkat partisipasi masyarakat dalam pengelolaan hutan Nagari di Sumatera Barat. Jurnal Penyuluhan. 3(1): 14-30.

Wardojo. 1992. Pendekatan Penyuluhan Pertanian untuk Meningkatkan Partisipasi Masyarakat. Di dalam: Hubeis AVS, Tjitropranoto P, Ruwiyanto W, penyunting. Penyuluhan Pembangunan Indonesia: Menyongsong Abad XXI. Jakarta (ID): Pustaka Pembangunan Swadaya Nusantara.

Wibisono, A.F., Dewi, P. 2014. Sosialisasi bahaya membuang sampah sembarangan dan menentukan lokasi TPA di Dusun Deles DsJagonayan Kec Ngablak. Jurnal Inovasi dan Kewirausahaan Seri Pengabdian Masyarakat.3(1): 21-27. ISSN: 2089-3086.

Zulkifli, A. 2014. Dasar-Dasar Ilmu Lingkungan. Jakarta (ID): Salemba Teknika 